\title{
"If I had wanted to put it into words, I would have written a novel": Ernő Dohnányi as Interviewee ${ }^{1}$
}

\author{
Veronika Kusz \\ Institute of Musicology \\ Research Center for the Humanities \\ of the Hungarian Academy of Sciences \\ Táncsics Mihály u. 7. 1014 Budapest, Hungary \\ E-mail: kusz.veronika@btk.mta.hu
}

(Received: August 2017; accepted: October 2017)

\begin{abstract}
Compared to his contemporaries Béla Bartók and Zoltán Kodály, Ernst von Dohnányi (1877-1960) did not leave an extensive legacy of prose writings. He rarely spoke either of himself, the background of his compositions, his musical principles or compositional aesthetics; nor was he particularly active as a musicologist, ethnomusicologist or critic. Yet, during a long life filled with wide-ranging professional activities, he authored numerous writings pertinent to the history of music and musical life. Equally informative are the interviews he gave in his various capacities as composer, performer, teacher, and institutional leader. A volume in progress, entitled Ernö Dohnányi's Selected Writings and Interviews, will offer an annotated critical edition of these texts (collected and edited by the author, to be published in late 2019). This study is based on the collected interview-material and gives a summary of some of their most important topics such as Dohnányi's views on modern music, creative and reproductive talents, live-, radio-, and recorded performances. Though these transcripts cannot always be considered authentic sources, this study attempts to show that there is a great deal of information, heretofore unknown, contained in the numerous new interviews our research has brought to light.
\end{abstract}

Keywords: Ernst von (Ernő) Dohnányi, interview, edition of his writings

"We must seize the moment when the Maestro is in an exceptionally good mood for an interview. Journalists can relate how rare an occasion that is. Ernő Dohnányi, king of music, usually ducks questions with a gentlemanly

1. This study was supported by a János Bolyai Research Scholarship from the Hungarian Academy of Sciences and a scholarship by Hungarian National Research, Development and Innovation Office (NKFIH 123819). 
reticence." ${ }^{2}$ So wrote one such, probably not without cause, of a Dohnányi interview made in the 1940s. A decade earlier, one inquisitive colleague had been chided by the composer: “... an artist's private life is not for putting to the public, for there are his works, his artistic attainments, and his home life can tell no more than they do." “ "... what arises from that meditation [on his works] will reach the public in any case; his own, my own life is mine, and cannot be of concern to anyone." "It is hard to get an interview out of me." "I'm not in the habit of making statements ..." "I have nothing to say on this." "Such remarks are ubiquitous. Hardly a Dohnányi interview lacks them. Yet there may have been another motive when journalists underlined Dohnányi's reserve. Often they seem to be excusing their own modest results when they blame short, often pointless discussions on their subject's extreme reticence. Vital questions and answers seem lacking from their pieces, while the composer is allowed to be long-winded on such inessentials as annoying cleaning schedules at a provincial hotel. ${ }^{8}$ The press coverage in various Dohnányi collections (at the British Library, Hungarian National Széchényi Library, Institute for Musicology of the Research Center for the Humanities of the Hungarian Academy of Sciences, or Florida State University) includes only a few interviews - many of them with remarks on their subject's reticence. So scholars have disregarded such sources hitherto. The first monographer, Bálint Vázsonyi, contented himself with simplification:

\begin{abstract}
Dohnányi did not speak willingly of his compositions ... he did not write books or talk about himself in interviews ... And if he cannot resist the pressures from American journalists, he talks instead of Bartók, Kodály, the history of Hungarian folk music research, [or] the origins and structure of Hungarian folk song. ${ }^{9}$
\end{abstract}

2. "Meg kell ragadni az alkalmat, amikor a Mester kivételesen nyilatkozó kedvében van. A riporterek elmondhatnák, milyen ritka alkalom ez. Dohnányi Ernő, a muzsika királya, az úr zárkózottságával tér ki minden kérdés elől." Pál Taksonyi, "A mai népi magyar zene nem hozott újat a modern zeneszerzés szempontjából. Dohnányi Ernő nyilatkozik az Összetartásnak” [Today's Hungarian folk music brought nothing new to modern composition. Ernő Dohnányi speaks to Összetartás], Összetartás 1/45 (12 November 1943), 5.

3. “... a művész magánélete nem a nagyközönség elé való, hiszen ott vannak a munkái, a művészi teljesítményei, ezeknél többet, különbet az otthona semmi esetre sem nyújthat senkinek.” Unsigned, "Művészéletek. Dohnányi Ernőék otthonában” [Artists' lives. In the Dohnányis' home], Rádióélet 3/45 (6 November 1931), 2012.

4. “... ami ennek az elmélyedésnek az eredménye, az úgyis a közönség elé kerül, míg a többi: a maga élete, az enyim, és nem is érdekelhet senkit.” Ibid.

5. “Tőlem nehéz interjút kapni ...” István Berente Jr., "Látogatás a magyar muzsika fejedelménél” [Visit to the prince of Hungarian music], Gödöllöi Hírlap (3 October 1943), 2.

6. "Nem szoktam nyilatkozni ...” Taksonyi, "Dohnányi Ernő nyilatkozik az Összetartásnak," 5.

7. "Erről nem nyilatkozom.” Ibid.

8. Miklós Guttmann, "Dohnányi Ernő. Nagyváradi interjü” [Ernő Dohnányi. Interview from Nagyvárad], Zenei Szemle 10/8 (June 1926), 245-246.

9. In context: "Dohnányi did not speak willingly of his compositions. He often cited Goethe: 'Create, artist, do not talk!' Indeed his whole life evinces that conviction. This is one reason why posterity knows so little about him. It would make a rich and colorful reading if he had once written an autobiography. But he did not 
Apart from the tendentious remark about Dohnányi's habit of speaking on folk-music matters, ${ }^{10}$ Vázsonyi's report is not unfounded. True: compared to his contemporaries Béla Bartók, Zoltán Kodály, or even László Lajtha, he did not leave an extensive legacy of prose writings. Yet in a long life filled with wide-ranging professional activities (not only as a composer/pianist but as a teacher and the head of various musical institutions), he produced numerous writings pertinent to the history of music and the music scene: memoirs, articles and lectures on pedagogy, organization proposals, and so on. Indeed recent research also belies Vázsonyi's claim about the restricted number and significance of Dohnányi's press statements/interviews. A remarkable number of interviews have been rediscovered during the current work on Ernö von Dohnányi's Selected Writings and Interviews. ${ }^{11}$ In addition, there is much fundamental, hitherto unknown information in the numerous interviews the research has brought to light. And though such transcribed discussions should not be seen as authentic sources, they provide valuable clues for our understanding of Dohnányi's musical thinking, his convictions, and his motivations as an institutional head. The volume of Dohnányi's writings and interviews will contain - keeping the harmonious proportion in mind - some twenty of the most interesting interviews, whose selection is still in progress, along with the research into the press. This study, however, summarizes the main lessons learned from the whole material, altogether more than 50 longer or smaller discussions published in daily newspapers and specialist journals, or broadcast on radio channels.

In selecting interviews for the planned volume, the aim has been for some chronological balance, to cover each stage of Dohnányi's life. Yet clearly the published conversations are spread over the decades unevenly, for several possible reasons.

write books or talk about himself in interviews. He speaks to us exclusively in music and in surviving letters mostly written to his younger sister. And if he cannot resist the probings of American journalists, he speaks of Bartók, Kodály, the history of Hungarian folk music research, the origins and structure of the Hungarian folk song." In the original: "Dohnányi nem szívesen beszélt műveiről. Gyakran idézte Goethét: »Alkoss, művész, ne beszélj«. S valóban, egész élete tanúskodik e meggyőződéséről. Többek között ezért is tud annyira keveset Dohnányiról az utókor. Pedig bizonyára gazdag és színes olvasmány lett volna, ha egyszer önéletrajzot ír. Dohnányi azonban nem írt könyveket, s nem nyilatkozott önmagáról. Kizárólag a zenén s hátramaradt elsősorban húgához írott - levelein keresztül szól hozzánk. És ha már nem tud ellenállni az amerikai újságírók unszolásának, Bartókról, Kodályról beszél, a magyar népdalkutatás történetéröl, a magyar népdal eredetéről és szerkezetéről.” Bálint Vázsonyi, Dohnányi Ernő (Budapest: Nap Kiadó, ${ }^{22002), ~} 299$.

10. Vázsonyi was probably relying here on an interview where Dohnányi indeed mentioned such matters, but it was rather an exception: Joan Holley, "I Interview Ernst von Dohnanyi," The Southwestern Musician (June 1952), 9. A cutting of this appears in his legacy (Dohnányi Collection - Bálint Vázsonyi’s Legacy: K 44-021; Archives for 20th-21st Century Hungarian Music, Institute for Musicology RCH of the Hungarian Academy of Sciences [hereafter AHM Dohnányi]).

11. Publication in Hungarian is planned for 2019 and an English version is also in progress in cooperation with James A. Grymes. 
Certainly, as Dohnányi aged and became more famous, he gained in interest for the press. Interviews as a genre became more fashionable after the 1930s, having been popularized by the propaganda efforts of the World War I period. As Dohnányi's administrative duties grew in the 1930s, his informatory communications with the press grew more frequent. Imbalances in his interview output may also arise from cultural differences between countries he visited. "I thought this would only happen in America, and see, I even meet American-style journalism before my departure, while I'm still at home," Dohnányi remarked before his United States tour in 1925, as he faced curious journalists and photographers. Finally, as an émigré whose reputation was being besmirched, the aged composer may have changed his interview stance, never having been too comfortable about them in the first place. Listing the publication venues summarizes Dohnányi's path in life: in his younger years various European cities, in the later 1920s and 1930s a predominance of Budapest journals, and later countries marking stages in his emigration: Austria, Britain, Argentina, and finally the United States. The main topics are also telling: initially they often treat of his childhood, his masters, the daily doings of a concert pianist; in the middle period, he is asked about institutions he led, for example concert tours by the Philharmonic Society, program structure at the radio, evaluation of a completed semester at the Liszt Academy of Music, and so on; in the final years grimmer motifs appear: war, emigration, and aging. Again there are phases in Dohnányi's relations with journalists. The directness of early questioners gradually became more aloof and respectful, and by the late 1930s almost servile and humble, while Dohnányi himself became more outspoken. After his emigration there appeared a special image, of a beloved, respected old maestro, who had arrived from far and long ago, and was treated to jovial interviews (see Plate 1). Of course, these stages have more to do with reception and the attributes and similes journalists used to describe him, which are worth exemplifying: "Boyish frankness, simplicity, and homeliness" - so a London journalist described the 21-year-old pianist; ${ }^{12}$ while to a Norwegian colleague, the interviewee had the "smiling lips of a child" and "great childish eyes," even at the age of $30 .{ }^{13}$ Another twenty years later an interviewer saw Dohnányi as a "nice, friendly man good at laughing ... [who] does

12. Unsigned, "About Dohnányi. The Latest and Youngest Star Pianist," The Daily Chronicle (3 December 1898). The interview was published by László Gombos, "Dohnányi Ernő müvészi tevékenységének sajtórecepciója. II. rész: A nemzetközi karrier kezdete, 1898. október - 1901. április” [Press reception of Ernő Dohnányi's artistic activities. Part II. The beginning of the international career, October 1898 - April 1901], in Dohnányi Évkönyv 2004, ed. Márta Sz. Farkas (Budapest: MTA Zenetudományi Intézet, 2005), 139.

13. In the Norwegian: "smilende Barnemund," "hans store Barneøine." Claire, "Hos Dohnányi," Orebladet (10 October 1906). The interview was published by László Gombos, "Dohnányi Ernő művészi tevékenységének sajtórecepciója. IV. rész: Az 1905-1909-es berlini évek” [Press reception of Ernő Dohnányi’s artistic activities. Part IV. The Berlin years, 1905-1909]", in Dohnányi Évkönyv 2006/7, eds. Márta Sz. Farkas and László Gombos (Budapest: MTA Zenetudományi Intézet, 2007), 152. 
not appear to be fifty." ${ }^{14}$ Journalists were unsparing of descriptive color when describing him at the height of his career. As one put it:

His name is so united with music that it has become almost musical itself. If one hears it, it is impossible not to think of Beethoven or Schubert, and softly touched scales sound in one's ears, as a gourmet's mouth will water at the words "grilled cutlets". 15

These lines were written in 1942, when Dohnányi was advancing in years. The same journalist likened him to "the materialized Andante movement of a Mozart sonata, with his blue eyes, white hair and soft lines of face." 16 However, an unexpected accelerando seems to have ensued, judging from the introduction to one of his very last interviews:

He gestured frequently with hands like sculpted marble, combining the restless energy of a college student with the quiet wisdom of 81 years devoted to composing, conducting and teaching music. Dean of the world's living composers, Dohnányi is the last of the great Romantic Age masters. He shows no signs of slowing down. ${ }^{17}$

In the interviews given in the first half of his life, Dohnányi is usually presented as a pianist. So the discussions mainly touch three topics: favorite composers, favorite pianists, and practicing techniques or habits. The first two are rather a result of perplexity: the journalists probably asked the same of every guest pianist. Still, it may be important that a twenty-year-old named as his favorites "among the moderns [!] Brahms; Schumann comes next.” Of course, he added, he loved Bach and Beethoven. ${ }^{18}$ As years and decades passed, however, he seemed reluctant to name a favorite composer: "It's a question of mood what I like to play most,"19 he said. Sometimes he compared a musical making to acting: "the reproduction

14. “... kedves, barátságos ember, aki nagyszerűen tud nevetni ... az ötven esztendő nem látszik meg rajta.” Kristóf Károly, "Dohnányi Ernő útja a bot-vonótól és bot-hegedűtől a világhírnévig” [Ernő Dohnányi’s way from the stick bow and stick violin to world fame], Színházi Élet 18/46 (13-20 November 1927), 67-68.

15. "Neve annyira összeforrott a muzsikával, hogy szinte zenei csengésü. Ha hallja az ember, lehetetlen nem Beethovenre, Schubertre gondolnia, s fülében lágy billentésü hangsorok csendülnek fel, mint ahogy összefut a nyál az ínyenc szájában, aki előtt kiejtik a »rostélyos« szót.” Dénes Szánthó, "Beszélgetés Dohnányi Ernővel” [A talk with Ernő Dohnányi], Magyar Nemzet 5/55 (8 March 1942), 10.

16. “... kék szemével, fehér hajával, lágy vonásaival olyan, mint egy Mozart-szonáta testet öltött andante-tétele." Ibid.

17. Clarence Jones, "Florida's Youthful Oldsters - Last of the Romantic Age Masters Not Slowing Down," The Florida Times-Union (5 October 5 1958) [from scrapbook: AHM Dohnányi, MZA-DE-Ta-Script 5.023/25].

18. Unsigned, "About Dohnányi. The Latest and Youngest Star Pianist," The Daily Chronicle (3 December 1898). The interview was published by László Gombos, "Dohnányi Ernő müvészi tevékenységének sajtórecepciója. II. rész,” 139.

19. "Hangulat kérdése, mit játszom a legszívesebben.” Szánthó, “Beszélgetés Dohnányi Ernővel,” 10. 
is perfected further if the performer's personality comes closer to the composer's. A performer who does not understand the composer cannot understand the work either." ${ }^{20}$ The discussions of practicing technique may be more interesting to posterity - Dohnányi usually gave shock answers. Legend has it that he did not practice at all. The interviews seem to justify these incredible stories. In his younger years he dismissed remarks about his diligence, saying his perfect technique came from special manual skills inherited from his father. Later he made no such apologies, even claiming that if "anyone practices a lot it is either out of unease or because his piano playing is technically incorrect." ${ }^{21}$ In his last interviews, he confessed that he too had been practicing for some years, as his fingers were aging. But, he added that he practiced études and finger exercises, not the pieces themselves.

Sporadic hints in the interviews clarify that Dohnányi did indeed not practice his concert pieces. And this brings us closer to some essential questions and problems. As he put it, he had acquired his whole repertoire in his youth (before and some years after graduating from the Liszt Academy of Music in 1897). He said also he was able to memorize many pieces while teaching. As he said at the age of 60:

The pieces I played in my youth were imprinted in my memory so sharply that I could play any of them any time, even starting up from my night's sleep ... Once my son worried me anxiously about not preparing for my evening recital. I calmed him saying that I had learned them all thirty or forty years ago, [and so] I never need practice them again. ${ }^{22}$

20. “a reprodukálás ... annál tökéletesebb, mennél jobban közel áll az előadóművész egyénisége a zeneszerzóéhez. Ha a müvész nem érti meg a szerzőt, nem tudja megmutatni a müvet sem.” Zoltán Egyed, "Dohnányi Ernő a zene örök hatásáról, a jó és a rossz zenéről, a mester és tanítvány kapcsolatáról és a nő igaz hivatásáról" [Ernő Dohnányi on the eternal influence of music, on good and bad music, the relationship of master and pupil, and the true vocation of woman], Film, Színház, Irodalom 6/8 (19-25 February 1943$), 9$.

21. "aki sokat gyakorol, az vagy idegességből teszi, vagy azért, mert zongorázásának módszere technikai szempontból helytelen”. Taksonyi, “Dohnányi Ernő nyilatkozik az Összetartásnak,” 5.

22. "Az ifjú éveimben játszott zenei müvek olyan élesen emlékezetembe vésődtek, hogy ezeket ma is akármikor, éjszakai álmomból felzavarva is el tudnám játszani. ... Egy ízben a fiam aggodalmasan figyelmeztetett, hogy az esti hangversenyre nem készültem. Megnyugtattam, hogy azt, amit harminc-negyven évvel ezelött megtanultam, soha többé átjátszanom már nem kell.” Géza Haits, "A krokodilbőr táska kincsei. Látogatás a hatvanéves Dohnányinál" [Treasures in the crocodile-leather bag. A visit to sixty-year-old Dohnányi], Ünnep 4/23 (1 August 1937), 45. 
Plate 1 Dohnányi's first interview in Tallahassee (6 November 1949), newspaper clipping in a scrapbook (Dohnányi Collection of the Archives for 20th-21st Century Music of the RCH Institute for Musicology of the Hungarian Academy of Sciences,

MZA-DE-Ta-Script 5.014/3)

\section{DOHNANYI PLANS CONCERT}

Master Musician Joins FSU Faculty.

By BETTY PATTERSON

A celebrity is in our midst. He is Ernst. von Dohnanỹi, one and a new member of the Schoo of Music faculty at Florida State

The public will be privileged to hear him in concert tomorro torium as an event of the Artist series.

Mr Dohnanyl, renowned Hungarian composer-pianist, came to Tallahassee from Argentin where he organized a school of

"Everything is so green here," he said. "that I have the impression it is summer." The musician like Argentina, a country he likes very much.

Dean of the School of Music Karl Kuersteiner has had a flurry of letters since Dohnanyi cam sity is to have the cote the UniverHow long Dohnanyi will be at FSU is anybody's guess. "I a here-that is all," he commented Do

at the anyi began studying music public recital at nine his first lauded at 17 by Johannes Brahms for an extended work, "Quintet In c major. entation.

At Florida State Dohnans teaches advanced students pian and composition. At present he has about a score of piano stu-
dents and three composition pudils.
pils and three composition puThe composer was reared in a father played the violin and flute and his father, a mathematics and physics professor, was a skilled When Do

Wohnanyi was 15 , his was premiered in a piano quarte Duesbuerg Quartet, with the com poser at the piano. Today his "Quintet" is still in the repertoire of chamber groups the world concertos for the piano, cello and orchestra. masters. "Everything that grand and "great, I admire," he
declared. "But the best of the
TALLAHASSEE DEMOCRAT, TALLAHASSEE, FLORIDA Sunday Morning, November 6, 1949 21 Production. Marke

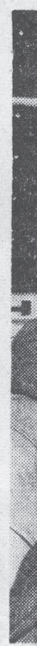

NOTED COMPOSER-Shown here is Enst von Dohnanyi, composer-pianist, and a COMPOSE-Shown here is Ernst von Dohnanyi, composer-pianist, in concert tomorrow evening in Westcott auditorium at $8: 15$.

moderns, I think, are Bartok and | tragedies occurring in Commumuvinsky?" Dohnanyi knew both nist dominated Hungary, accordmim.

arl Goldmark of Edward Grieg, "They have taken everything," chim, violinist. Joachim, director of the su- Dohnanyis, sensing the turn perior school of music in Berlin, the tide, left the country in 1944 . pohnanyi, his wife, son, Julio, , 18 , and daughter. Helen, 20 , are there for 10 years. He then went to Budapest Julio arrived only this weekend. where he directed the Academy He and Helen are enrolled in FSU, of Music, and was principal con- where she ductor of the Budapest Philharmonic society until 1946.

cusical development in Amerhas astonished me," he said When Dohnanyi first came to the United States 50 years ago, only a handful of symphony orchestras existed in the nation. "Now there The too many to count, "he sald. at last to appreciate music. Doh With orchestras in conplaced on the arts in our schools The master hopes to return to B minor was given its American Hungary some day, "but that of premiere by the Detroit Symphony "Europe is very sad" he contin- concerto was hailed as a ". The ued. "Some of our most beautiful companion piece to his wellcitles have been destroyed."

Many of Dohnanyi's friends ofe cident is only one of countless of the melodic and architectural the melodic and ardal ne and use of the pedal. As and serenity of one the indevoted his life to the creation of beauty.

The composer will present a second recital at the university 
Of course, it is hard to describe his congenial, inconceivable musical memory. Maybe these lines say most about this:

As a conductor I read the orchestral scores with such attention I can memorize the connecting musical phrases, and so I can, of course, learn them far more easily, almost involuntarily. If I conduct a work several times in succession, as I did recently, I do not need the conductor's score for the third performance. ${ }^{23}$

The question remains whether this morsel of information explains satisfactorily the stories about Dohnányi being able to recall pieces he had once sight-read decades ago.

Also of interest to posterity is Dohnányi's œuvre as a composer. Yet the talk rarely turned to deeper aspects of his creativity. If he spoke of a work, he would describe briefly its genesis or mention some plans for it. He seems unable to bear speaking of more essential, interesting features such as style, inspiration, or analytical motifs. "What is it like?" he repeated with annoyance to a journalist who had asked about his new Suite en Valse op. 39. "It is music. Just that. If I had wanted to put it into words, I would have written a novel." ${ }^{4}$ Only to a few works can he bring himself to devote a sentence or two. However, his American Rhapsody op. 47 he discussed at greater length, maybe because the questioners, student journalists of Ohio University and commissioners of the piece, were highly enthusiastic and persistent. Their eagerness gave rise to several interviews rich in content ${ }^{25}$ and to Dohnányi's longest piece of self-analysis. ${ }^{26}$ Apart from American Rhapsody, his works seem to have spurred only passing remarks. One example: it emerged from the interview collection that Dohnányi had worked on his large chamber Sextet op. 37 for far longer than other sources implied. ${ }^{27}$

23. "Mint karmester a partitúrákat már azzal a figyelmességgel is olvasom, hogy az egymásba kapcsolódó zenei mondatokat megjegyezzem, s így persze sokkal könnyebben, szinte akaratlanul is megtanulom őket. Ha valamelyik mủvet többször vezénylem egymásután, mint nemrégiben is, a harmadik előadáson már nincs szükségem vezérkönyvre." Ibid.

24. "Hogy milyen? Zene. Így, egyszerủen. Ha szavakban lehetne kifejezni, akkor regényt írtam volna." Taksonyi, "Dohnányi Ernő nyilatkozik az Összetartásnak," 5.

25. E.g. Myron Henry, "Would Join OU Faculty: Interview With Composer von Dohnanyi Furnishes Interpretation of $\gg$ Rhapsody«," Ohio University Post (26 February 1954) [from scrapbook: AHM Dohnányi, MZADE-Ta-Script 5.017/25]; Walt Rosinski, "Brahms Encouraged Dr. von Dohnanyi To Perform First Work at Age of 17," Ohio University Post (17 April 1953) [from scrapbook: AHM Dohnányi, MZA-DE-Ta-Script 5.016/23], Ralph Kliesch, "World-Famous Composer-Pianist... Dr. Dohnanyi Revisits Campus...," Ohio University Post (18 February 1954) [from scrapbook: AHM Dohnányi, MZA-DE-Ta-Script 5.017/21].

26. Dohnányi's program note to American Rhapsody, typescript [undated, c. 1954] (OU Alden Library, Baker Files, no shelf mark).

27. He had mentioned the piece in summer 1932 (“A Filharmóniai Társaság hangversenyei” [Concerts of the Philharmonic Society], Rádióélet 4/43 [21 October 1932], 1791), yet the composition date given in the var- 
Dohnányi seems to have been more talkative as an interviewee when asked about his general esthetic views - and such paragraphs are of essential importance here too, as Dohnányi wrote no texts of his own on such matters. Of course, he was an accomplished artist when he formed his clearer opinions. One ominous question first arose in 1926 (its form itself insinuating his view): "What is your point of view, Maestro, against [my italics] the style of the atonalists?"28 During World War II, Dohnányi became more and more outspoken, even provocative in his opinion of modern music, whereas in his émigré period he became more cautious again, a change perhaps not unconnected with his view that the political calumnies against him were in part marks of professional revenge by modernist composers. ${ }^{29}$ But why did he see most contemporary composing techniques as problematic? To sum up his responses, he thought that many (or most) of his contemporaries' works were thin in content, but convoluted in structure and technique. He believed their artificiality and effort at originality allowed less qualified composers to predominate, the huge technical apparatus being used to hide absent professional knowledge. He also saw "thin content" as a natural consequence of a specific situation in music history: "The job of a composer gets harder and harder. The more said before, the less remains to be said." ${ }^{30} \mathrm{He}$ supposed his colleagues were fully aware of this. As he said in the interview just quoted:

They try to cover up the thin content by exaggerating the form. That is how so-called modern music comes about, most of it being nothing other than a spasmodic quest for originality. The classicals never tried to appear original: they just were. Modern music composition stumbles along dark alleys because it lacks natural tasks. ${ }^{31}$

ious catalogs is 1935. Cf. Imre Podhradszky, “The Works of Ernő Dohnányi,” Studia Musicologica 6 (1964), 357-373; Deborah Kiszely-Papp, Ernő Dohnányi, ed. Melinda Berlász (Budapest: Mágus Publishing, 2001) (= Hungarian Composers 17).

28. "Milyen álláspontot foglal el [a] mester az atonalisták stílusával szemben?” Guttmann, "Nagyváradi interjú," 245.

29. Intensive research into Dohnányi's political problems continues. For an earlier summary in English, see Ilona von Dohnányi, Ernst von Dohnányi. A Song of Life, ed. James A. Grymes (Bloomington/Indianapolis: Indiana University Press, 2002), 127-151.

30. “... a zeneszerző dolga mindig nehezebbé válik. Minél többet mondtak el előtte, annál kevesebb elmondandó marad hátra.” Szánthó, "Beszélgetés Dohnányi Ernővel,” 10.

31. "A tartalom soványságát a forma felnagyításával igyekszenek pótolni. Így jön létre az úgynevezett modern zene, amely túlnyomórészt nem egyéb, mint eredetiségek görcsös keresése. A klasszikusoknál senki se igyekezett eredetinek látszani: egyszerüen az volt. A modern zeneszerzés mellékvágányokon bukdácsol, mert hiányzanak természetes feladatai." Ibid. 
The composer had a special definition for modern music: it was all that quickly lost validity:

The crop of previous years that we have forgotten was modern at the time. What survives has become part of humanity's permanent values, and sooner or later becomes classical. With a little generosity I can say that modern music is up-to-date, but with an equal amount of malice I say it is ephemeral. And today modern means mechanistic. ${ }^{32}$

Only in two interviews did he talk of different contemporary styles. First, when he briefly listed those who were not to his taste: atonalists, "hyper-moderns, the new Russians and new French." 33 The second case when folksy tendencies were mentioned. This interview deserves attention in several ways, as it was published in the journal of the extreme right-wing Hungarian Arrow Cross Party, Összetartás [Solidarity], in November 1943. The Arrow Cross Party would lead Hungary in the final phase of World War II (under German occupation), resulting a reign of terror between 15 October 1944 and 28 March 1945. Its publication Összetartás was a weekly journal, edited by Ferenc Fiala, and first appeared in 1937, but was banned several times. It is understandable that the political rumors around Dohnányi scored this article as an offense, and it contained, moreover, one of the lengthiest remaining conversations with him. The journal regularly published similar portraits with outstanding personalities, but it can be assumed that the interviewees were selected for their ideological sympathy. For a present-day scholar, it is baffling to find Dohnányi agreeing to an interview in so questionable a journal. He never expressed his political opinions in print (except in his émigré period, when asked about prevalent Communist rule). ${ }^{34} \mathrm{He}$ never joined any political party, and later on, when the Arrow Cross Party was in power, he had sharp conflicts with their apparatus that quickly led to his emigration in November 1944. Did the journalist from Összetartás find Dohnányi, obviously irritated by certain cultural-policy steps being taken at the time, pick just the right moment? Or did Dohnányi agree to appear due to other circumstances still unknown to us? Had he given his blessing to the published text (or was he ever asked for his approval)? For not only the vehicle, but the tone of the interview is shocking - cynical and unhindered. Present-day readers rightly feel that Dohnányi lost

32. "A pár évekkel ezelőtti termésből modern volt az, amit ma már elfelejtettünk. Mert ami megmaradt, az besorozódik az emberiség állandó értékei közé és előbb-utóbb klasszikussá válik. A modern zenére tehát egy kis jóhiszemüséggel azt kell mondanom, hogy korszerü, ugyanannyi rosszhiszemüséggel, hogy múlandó. És végül modern manapság az, ami elmechanizálódott.” Ibid.

33. Guttmann, "Nagyváradi interjú," 245.

34. For example: Martin Dyckman, "Hungarian-Born Dohnanyi Marvels At Courage of Anti-Russian Patriots," The Florida Flambeau (2 November 1956) [from scrapbook: AHM Dohnányi, MZA-DE-Ta-Script 5.020/49]; Ron Hamm, "Nephew Of Dohnanyi. PhD Describes Freedom Flight," Tallahassee Democrat (14 April 1957) [from scrapbook: AHM Dohnányi, MZA-DE-Ta-Script 5.023/13]. 
control and divorced himself from the actual Hungarian music scene with these offensive and intolerable opinions. This is all the more remarkable because he was still heading the Philharmonic Society and the music division of Hungarian Radio at the time, and he had resigned his directorship of the Liszt Academy of Music over the forced expulsion of a Jewish ex-student and friend, György Faragó. Contemporaries too were perturbed by the interview, as a lengthy reaction by Endre Gaál makes clear. ${ }^{35}$ Gaál, though a close and sympathetic colleague of Dohnányi, wrote respectfully, but his text is full of attributes like "surprising," "startling," and "weird." One of the most shocking moments in the interview was Dohnányi's pronouncement about the folk music of common people as an inspiration:

The composer turns to the folk for material if he does not have original ideas. One can notice a certain general infertility in composition. Composers do not create, but borrow a theme. "If we do not have any, let's steal one from the folk," they say. ${ }^{36}$

He went as far in his provocation as to answer with a decided "no" when asked, "Has folk music brought anything new and significant in the aspect of modern, progressive composition?" It is yet more unfortunate that the journalist should have chosen this provocative response as the interview title: "Present-Day Hungarian Folk Music Brought Nothing New to Modern Composition. Ernő Dohnányi Interviewed by Összetartás." But despite all this, the interview needs reading carefully, for Dohnányi explained these thoughts in it in a more subtle way:

Those who turn to the folksy direction in music can produce something, I don't say that they can't. But it is not the real thing. It is not natural enough, artificial rather than artistic. Too affected, forced. It is a consequence of a painful search. See for example the folk songs. The composer only arranges them with the aid of his musical training. He uses the folk songs, but no new musical trend develops from that. A development would be if the folk should produce great musical works. But it is not what is happening now. The urban composers who have long been detached from the folk, from the ancient roots, borrow from the folk. This borrowing only has some individual color if the composer has a

35. Endre Gaál, "Dohnányi Ernő esete a mai magyar zeneművészettel” [Ernő Dohnányi’s case with present-day Hungarian music], Magyar Nemzet 7/35 (13 February 1944), 13.

36. "Ha a szerzőnek nincs eredeti mondanivalója, akkor fordul a néphez témáért. A zeneszerzés terén általában ma bizonyos meddőség észlelhető. A zeneszerzők ma nem komponálják, hanem kölcsönkérik a dallamot. »Ha nekünk nincs, lopjunk a néptől« - mondják." Taksonyi, "Dohnányi Ernő nyilatkozik az Összetartásnak," 5 . 
personality. The time will arrive when the world will exploit the new musical language in this. For now, it is incalculable. ${ }^{37}$

\begin{abstract}
Also important (and perhaps a factor behind the interview) was a recent contemporary music series of a scandalously low standard. ${ }^{38}$ The Week of New Hungarian Compositions [Új magyar zenemüvek hete], on 24, 26, and 28 May 1943 at the Liszt Academy, featured works by Jenő Ádám, Gyula Bandó, Zoltán Gárdonyi, Elemér Gyulai, Mihály Hajdu, Zoltán Horusitzky, Jenő Kenessey, Tivadar Országh, Ferenc Ottó, Zoltán Pongrácz, Endre Szervánszky, Dénes Tóth, Jenő Vécsei, and Sándor Veress. Dohnányi passed an ironic comment on this:
\end{abstract}

It is strange how official circles excluded from the official première the works of such notable musical personalities as Béla Bartók or Zoltán Kodály, but now arranged three concerts, one after the other, for the tiny and insignificant, for those who do not count at all, or precious little. ${ }^{39}$

According to the few remarks in his interviews, and in some other writings, Dohnányi saw Bartók (and maybe Stravinsky) as exceptional among the modernists. ${ }^{40}$ But beyond Bartók, Dohnányi observed a general lack of creative talent that he believed was rather a sign of the times, and not because of the war or other circumstances. In his final Hungarian interviews (from about 1937 until his emigration in 1944) he willingly discussed his conviction:

\begin{abstract}
When culture has lived itself out to a certain degree, then comes the role of civilization. Civilization is always consequent on the decline of culture. We have gone beyond the point where culture and civilization fitted in side by side. We live comfortably, but we have less inner content to express. ${ }^{41}$
\end{abstract}

37. “A zenében, nem mondom, valamit produkálnak azok, akik a népi irányhoz folyamodtak. De ez nem az igazi. Nem elég természetes, inkább »művies«, mint művészi. Túlságosan csinált, erőltetett. Kínos keresgélésnek a következménye. Mert vegyük csak a népi dalokat. A zeneszerző teljes zenei fölkészültségével csak átdolgozza őket. Fölhasználja ugyan a népdalokat, de ebből nem fejlődik új zenei irány. Fejlődés az volna, ha a nép termelne ki önállóan, nagy zenei müveket. De nem ez történik. A nagyvárosok a néptől, az ősi gyökértől rég elszakadt zeneszerzői - kölcsönöznek a néptől. Ennek a kölcsönzésnek csak akkor van némi egyéni színe, ha a zeneszerzőnek van egyénisége. Majd eljön az idő, amikor a világ kitermeli a maga új zenei nyelvét. Hogy mikor lesz ez, egyelőre még beláthatatlan." Taksonyi, "Dohnányi Ernő nyilatkozik az Összetartásnak," 5.

38. Budapest Concert Database; Archives for 20th-21st Century Hungarian Music, Institute for Musicology RCH of the Hungarian Academy of Sciences: http://db.zti.hu/koncert/koncert_Kereses.asp (accessed on 11 June 2017).

39. “Különös, hivatalos körök annak idején elzárkóztak olyan jelentős zenei személyiségek műveinek hivatalos jellegü bemutatása elől, mint Bartók Béla vagy Kodály Zoltán, de most a kicsiknek és jelentékteleneknek, akik zenei szempontból semmit, vagy édeskeveset számítanak, három hangversenyt is rendeztek egymásután.” Taksonyi, "Dohnányi Ernő nyilatkozik az Összetartásnak,” 5.

40. See for example: Paul Fontaine, “Athens’ Writer Has Interview With Dr. Ernst von Dohnányi," The Sunday Messenger (19 December 1948) [from scrapbook: AHM Dohnányi, MZA-DE-Ta-Script 5.011/22].

41. "Amikor a kultúra egy bizonyos fokig kiélte magát, jön a civilizáció szerepe. A civilizáció mindig a kultúra hanyatlásának a következménye. Ma már túljutottunk azon a ponton, ahol a kultúra meg a civilizáció 
Here Dohnányi did not name a source, but his thoughts clearly came from the well-known German historical philosopher Oswald Spengler. His Decline of the West had been popular in Hungary since it first appeared in 1918. There are other sources for saying it was among Dohnányi's favorite reading matter. ${ }^{42}$ And it is no surprise that he could find in Spengler a philosophical background, even some justification for his own specific aesthetics of music. But most importantly (and this may be the ultimate lesson from the interview corpus), Dohnányi seems to have seen himself as exceptional. He did not think his œuvre could solve the problem or even that he himself as a major composer. He did not think his path would be the right one, or even the one that led on. The interviews point to a belief that his creativity arose as much out of a decadent age as did that of his colleagues. The one difference is his self-awareness: he accepted that under those conditions he could not write music like the old masters. Indeed he repeatedly stressed that his age lacked "creative talents," while "there are a great many reproductive talents, some truly excellent." ${ }^{\text {"43 }}$ Though Dohnányi defined himself as a composer, he presumably saw his composing as a kind of a reproductive process, perhaps as the one possible way in a given historical and cultural situation. Observations of this kind could be vital to analyzing basic traits in his musical style, such as richness in references and inspirations and other links to older musical styles.

$$
* * *
$$

Finally, it is worth dwelling on Dohnányi's remarks about radio and sound recordings. He made his piano debut at Hungarian Radio in 1927, only the second year of its existence. He joined its Musical Council in 1930. Then early in 1931, his considerable experience led to him being asked by the board of Hungarian Telephonic News and Radio Corporation [Magyar Telefonhírmondó és Rádió Rt.] to be Music Director of the "Studio." The many interviews that appeared in the Radio weekly Rádióélet [Radio Life] suggest that Dohnányi's activities there were of more importance to him even than his leadership at the Philharmonic Society or the Liszt Academy. Anyway, he certainly enjoyed his radio work, at least in the early years. He willingly spoke of the special atmosphere at radio recordings: for example of his very first experience in 1921 in New York, when he had to play in such a small room that he almost suffocated. He also spoke of acoustic problems: the dry sound called for in the earliest years of international radio, or his attempts

megfért egymással. Kényelmesen élünk, de kevesebb a belső mondanivalónk.” Egyed, "Dohnányi Ernő a zene örök hatásáról," 9.

42. See for example: Ilona von Dohnányi, Ernst von Dohnányi. A Song of Life, 146.

43. “... reproduktív tehetség ellenben sok van és némelyik igazán kitűnő.” Taksonyi, "Dohnányi Ernő nyilatkozik az Összetartásnak,” 5. 
to improve the orchestral sound. He stressed remarkably often the role of radio as a medium of public education:

In my view, almost anyone could be trained to enjoy the most serious music. The simplest and fittest way to do so is to draw them imperceptibly and entertainingly away from their immediate musical world, say Strauss waltzes or Hungarian popular songs, to the Ninth Symphony. This is a major task for the radio, too. ${ }^{44}$

He also related a startling example concerned with this:

The union of radio and music culture and their great common task are made clear by an interesting case a few years ago, at a dress rehearsal of the [Budapest] Philharmonic Society in the concert hall of the [Liszt] Academy of Music. There I noticed a peasant couple when I stepped onto the stage, sitting in the front row. During an interval in the concert, an acquaintance of mine asked them if they were there by accident. They said - as I immediately suspected that they had heard philharmonic concerts several times on the radio, and they finally wanted to see one. ${ }^{45}$

More interesting still is a remark about the relationship of chamber music and radio. Radio, he said, is the only medium that "brings all the enjoyable, lacily artistic elements into our room." ${ }^{\prime 6}$ The artistic development of radio recording is also connected to this modern intimacy of the studio. As he put it:

44. "Véleményem szerint majdnem mindenkit rá lehet nevelni arra, hogy a legkomolyabb zenét élvezze. Ennek a legegyszerübb és legcélszerübb módja, ha az illetőt észrevétlenül, szórakoztatva visszük el a hozzá közelálló zenei világból, mondjuk a Strauss-valcertől vagy a magyar nótától a 9. szimfóniához. Ez fontos feladat a rádiónak is." Egyed, "Dohnányi Ernő a zene örök hatásáról," 9.

45. "Rádió és zenekultúra közösségére, valamint nagy feladatára igen érdekes eset vet világosságot: néhány évvel ezelőtt az egyik filharmóniai hangverseny főpróbáján a Zenemüvészeti Főiskola nagytermében a dobogóra lépve egy parasztpárra esett a tekintetem. Épp az első sorban foglaltak helyet. A hangverseny szünetében egyik ismerősöm felkereste őket és megkérdezte, vajon nem tévedés-e, hogy idejöttek. Mire elmondták - amit azonnal gyanítottam -, hogy miután rádión keresztül már többször hallottak filharmóniai hangversenyt, egyszer látni is akartak ilyesmit." Ernő Dohnányi, "Rádió és zenekultúra" [Radio and music culture], in Rádióhallgatók lexikona. Az irodalom, zene, színház, film, rádió, rádiótechnika, gramofon és sport enciklopédiája [Manual for radio listeners. Encyclopedia of literature, music, theater, film, radio, radio techniques, gramophone and sport], eds. Andor Tiszay Andor, and Géza Falk (Budapest: Vajda-Wichmann, 1944), vol. 2, 243.

46. "Behozza szobánkba ennek a csipkefinom muzsikálásnak minden élvezhető artisztikumát.” Sándor Gyarmathy, "Próbálnak Dohnányiék" [Dohnányi and the orchestra rehearse], Rádióélet 4/28 (8 July 1932), 1098-1099. 
Anyone who plays frequently on the radio will gain an interesting awareness of caring about his playing much more, because he brings his mind to bear, I would say, on the mechanical work that he does when he is playing. ${ }^{47}$

So studio performance should be precise and thorough, but in the meantime free and intimate. Interestingly, Dohnányi believed that this kind of studio differed considerably from a studio for recording on disk:

Radio music is not mechanistic, because the conditions for making music on the radio today are just the same as for making music at home or in a concert hall. ... Sitting alone at the piano in a studio one can make music as freely as at home, as a twosome with the instrument. Recording music, however, is different. One has to simplify. In order not to become boring one has to make the music artificially duller. To make this paradox clear: the more rubato, the more free and spontaneous fantasizing there is on a gramophone recording, the faster the owner of the disk will develop an aversion to the piece, as he puts it on the turntable time and again. One has to be cool and objective here and this stops the recorded performer from becoming boring too soon. ${ }^{48}$

It is a colossal loss to posterity that Dohnányi's weekly radio recitals were not recorded (or the recordings were destroyed as in the case of all the Mozart piano concertos he played in the 1940s). However, this observation could shed light on why his disks are usually described as faint reflections of his live piano interpretations.

$$
* * *
$$

Apart from what has been related here, readers may come across many gems in the Dohnányi interviews - colorful moments, important information, and thought-provoking ideas. One learns, for example, of Dohnányi's views on the limits of higher musical teaching, of the concept behind the program structures and foreign concert tours of the Budapest Philharmonic Society, of his opinion of the art of conducting and contemporary conductors, of his daily routine, of his art of gardening,

47. “Aki sokat játszik rádión arra az érdekes tapasztalatra jut, hogy sokkal jobban vigyáz a játékra, mert minden figyelmét oda összpontosítja, arra a - mondhatnám - mechanikai munkára, amit végez, amikor játszik." Unsigned, "Dohnányi Ernő és a rádió (beszélgetés a mesterrel)" [Ernő Dohnányi and the radio. A talk with the maestro], Rádióélet 1/3 (11 October 1929), 10.

48. "A rádiózene nem mechanikus zene, mert a rádióban való muzsikálásnak ma már tökéletesen azonos feltételei vannak, mint a házi vagy teremi muzsikálásnak. ... ha az ember egyedül ül a zongoránál a stúdióban, olyan szabadon muzsikálhat, mintha otthonában lenne, kettesben a hangszerrel. A lemezre való játék azonban más. Ezt le kell egyszerüsíteni. Mesterségesen érdektelenné kell tenni, hogy unalmassá ne váljék. Úgy értendő ez a paradoxon, hogy minél több a rubato, a szabad és önkényes fantáziálás a gramofonlemezen, annál hamarabb megcsömörlik tőle a lemez tulajdonosa, ha sokszor forgatja le ugyanazt a számot. Itt tehát hüvös tárgyilagosságra van szükség, ami konzerválja a lemez előadóját a korai megunástól.” Szánthó, "Beszélgetés Dohnányi Ernővel," 10. 
of his childhood memories (he loved to talk of these). But he is also asked about the vocation of woman. To close, let me quote a notably bright and cynical answer he gave when asked "whether there are talented female composers:"

Female composers are as rare as before. Great creation is not women's element, they tend rather to have a talent for reminiscence. Formerly, I believed that women were not skilled either at mathematics or at composition. But recently I've met several women mathematicians. ${ }^{49}$

This has nothing to do with male chauvinism as such. Predictably, Dohnányi did not encourage contemporary male composers in that interview either.

49. “A zeneszerzésben ma éppen olyan kevés a nő, mint azelőtt volt. Az igazi nagy alkotás nem a nő eleme, inkább az utánaérzéshez van tehetsége. Régebben azt hittem, hogy a nő sem a matematikához, sem a komponáláshoz nem ért. Újabban azonban nagyon sok matematikusnővel találkoztam.” Ibid. 